\title{
IN VITRO DEVELOPMENT OF YELLOW LAPACHO (BIGNONIACEAE) USING HIGH-POWER LIGHT EMITTING DIODE ${ }^{1}$
}

\author{
Ezequiel Enrique Larraburu ${ }^{2 *}$, Gonzalo Sanchez Correa ${ }^{2}$ and Berta Elizabet Llorente ${ }^{2}$
}

\footnotetext{
${ }^{1}$ Received on 11.12.2017 accepted for publication on 30.10.2018.

${ }^{2}$ Universidad Nacional de Luján, Departamento de Ciências Básicas,Laboratório de Cultura de Tecidos Vegetais, Buenos Aires, Argentina. E-mail: <ezequiel.e.larraburu@gmail.com>,<escuelaetem@hotmail.com>and <bllorente@gmail.com>.

*Corresponding author.
}

\begin{abstract}
Handroanthus ochraceus (yellow lapacho) is a medicinal, ornamental and timber tree which can be propagated by in vitro culture. Conventional methods use fluorescent lighting (FL), whereas light emitting diode (LED) has been used for this purpose only recently. The aim of this work was to evaluate the effects of FL and high-power LED (HP-LED) on the in vitro multiplication and rooting of yellow lapacho at different irradiances ( 15 to $60 \mu \mathrm{mol} \mathrm{m} \mathrm{s}^{-2}$ ). Epicotyls obtained from half-siblings was multiplicated in WPM (Woody Plant Medium) supplemented with $20 \mu \mathrm{M}$ benzilaminopurine and $1 \mathrm{mM}$ IBA (indolebutiric acid). For rooting, shoots were cultured for 3 days in $1 / 2 \mathrm{WPM}$ supplemented with $50 \mu \mathrm{M}$ IBA and for 42 days in auxin-free $1 / 2 \mathrm{WPM}$ under HP-LED or FL lighting. Under HP-LED, the multiplication rate of shoots increased significantly (61\%) from 20 to $40 \mu \mathrm{mol} \mathrm{m}^{-2} \mathrm{~s}^{-1}$ respect to FL. Differences in abaxial stomatal density and size were observed between light sources at $20 \mu \mathrm{mol} \mathrm{m}^{-2} \mathrm{~s}^{-1}$. High HP-LED irradiance produced the highest rooting percentage. In the rooting stage, the marginal means of treatments without factors interaction showed that HP-LED irradiances significantly increased shoot length by $20 \%$, shoot fresh weight by $77 \%$ and shoot dry weight by $30 \%$ in comparison to the values under FL. The maximum values calculated from the regression curves were around $50 \mu \mathrm{mol} \mathrm{m}^{-2} \mathrm{~s}^{-1}$ for HP-LED for all parameters except root lenght whereas were around $20 \mu \mathrm{mol}$ $\mathrm{m}^{-2} \mathrm{~s}^{-1}$ for FL for all parameters except fresh and dry weig th of shoot. Here we show that HP-LED lighting improve in vitro culture of $H$. ochraceus, reduced $81 \%$ energy consumption respect to FL and uses only a multispectral LED instead of different single color LEDs. Therefore, HP-LED could be useful for the micropropagation of tree species contributing to sustainable agriculture and ecological restoration of degraded areas.
\end{abstract}

Keywords: Handroanthus ochraceus; Irradiance; Micropropagation.

\section{DESENVOLVIMENTO IN VITRO DE IPÊ-DO-CERRADO (BIGNONIACEAE) USANDO DIODOS EMISSORES DE LUZ DE ALTA POTENCIA}

RESUMO-Handroanthus ochraceus (ipê-do-cerrado) é uma árvore medicinal, ornamentais e um recurso de madeira que pode ser propagada por cultura in vitro. Os métodos convencionais de propagaçao usam iluminação fluorescente (FL) e recentemente os diodos emissores de luz (LEDs). Este trabalho avalia os efeitos do FL e do LED de alta potência (HP-LED) na propagação in vitro de ipê-do-cerrado em diferente irradiâncias de luz (15 a $\left.60 \mu \mathrm{mol} \mathrm{m} \mathrm{m}^{-2} \mathrm{~s}^{-1}\right)$. Epicótilos obtidos de família de meios-irmãos foram multiplicados em WPM (Woody Plant Medium) suplementado com $20 \mu M$ de 6-benzilaminopurina e $1 \mu M$ AIB (ácido indol-butírico). Para o enraizamento, os brotos foram cultivados por 3 dias em $1 / 2$ WPM suplementado com $50 \mu M$ IBA e por 42 dias em 1/2WPM sem auxina sob iluminação HP-LED ou FL. Sob HP-LED, a taxa de multiplicação dos brotos aumentou significativamente (61\%) de 20 para $40 \mu \mathrm{mol} \mathrm{m} \mathrm{m}^{-2} \mathrm{~s}^{-1} \mathrm{em}$ relação a FL. Foram observadas diferenças nas densidades e tamanhos estomáticas entre fontes de luz. A irradiância HP-LED elevada produziu o maior porcentagem de enraizamento. Na fase de enraizamento, as médias marginais dos tratamentos sem 
interação entre os fatores mostraram que as irradiâncias HP-LED aumentaram significativamente o comprimento da parte aérea em $20 \%$, a parte aérea fresca em $77 \%$ e a massa seca da parte aérea em $30 \%$ em comparação com os valores da FL. Os valores máximos calculados a partir das curvas de regressão foram em torno de $50 \mu \mathrm{mol} \mathrm{m} \mathrm{m}^{-2} \mathrm{~s}^{-1}$ para HP-LED para todos os parâmetros, exceto comprimento da raiz, enquanto em torno de 20 mol m $m^{-2} s^{-1}$ para FL, exceto fresco e seco peso de tiro. A iluminação HP-LED melhora a cultura in vitro de H. ochraceus, reduz $81 \%$ o consumo de energia em relação à FL e usa um LED multiespectral em vez de diferentes LEDs monocromáticos. Portanto, HP-LED pode ser útil para a microprogação de árvores contribuindo a uma agricultura sustentável e para a restauração ecológica de áreas degradadas.

Palavras-Chave: Handroanthus ochraceus; Irradiância; Micropropagaçao.

\section{INTRODUCTION}

Handroanthus ochraceus (Cham.) Mattos (=Tabebuia ochracea (Cham.) Stand1.) "yellow lapacho" is a tropical forest tree native to South America belongs to the Bignoniaceae family with plenty beautiful yellow flowers. This species is used as a timber resource for woodworking and naval manufacturing as well as a medicinal and ornamental plant. Conventional propagation of this species is by seeds but their germinative capacity decreased to $47 \%$ in eight months after harvest. In adition, it suffers from irregular reproduction linked to unseasonal frosts and its seeds are depredated by insects. which may remove up to $95 \%$ of total production (Justiniano et al., 2000; Apóstolo et al., 2016). The agricultural frontier expansion and climatic changes have led to a reduction of the natural populations and motivated researchers to use biotechnological methods, such as micropropagation and mycorrhizal inoculation, to increase Handroanthus and Tabebuia species mass propagation (Silva, 2004; Huante et al., 2012; Larraburu and Llorente, 2015; Llorente et al., 2016).

Light affects plant morphogenesis as main factor. It may not only induce plant development but also induce photo-inhibition when leaves are exposed to more light than they can utilize (George et al., 2008). Usually, fluorescent light is used for plant micropropagation in growth chambers with irradiances between 25 and $150 \mathrm{mmol} \mathrm{m}^{-2} \mathrm{~s}^{-1}$ for a $16 \mathrm{~h}$ photoperiod. However, this illumination source has some disadvantages such as its short lifespan (10000 h) and large volume, and the fact that it produces heat, which leads to the need of an extensive cooling system and high maintenance costs (Jao and Fang, 2003; George et al., 2008).

Revista Árvore. 2018;42(5):e420508
Light emitting diodes (LEDs) have been used as an alternative light source for controlled-environment agriculture (Nhut et al., 2003; Astolfi et al., 2012; Gupta and Jatothu, 2013; Apostol et al., 2015; Riikonen et al., 2016). The high efficiency in energy conversion of LEDs reduces the heat emissions and thereby saves energy. LEDs show improved longevity (five to ten times longer lifespan than fluorescent light (FL) tubes), have a small mass and volume, are environmentally safer than FL tubes (they do not have mercury), and are made with recyclable material (Astolfi et al., 2012).

There are several LED types that emit light at different wavelengths. The range of emission wavelength affects the morphogenetic response of plant. For example, the emissions of blue and red LEDs match closely with the absorption peaks of chlorophyll $a$ and $b$, and these wavelengths generate maximum photosynthetic efficiency, which in turn enhances bud development (Nhut et al., 2003). The effect of red and blue LEDs on the growth and development of plants of the genera Zantedeschia (Chang et al., 2003), Phalaenopsis (Jao and Fang, 2003), Fragaria (Nhut et al., 2003), Lactuca (Kim et al., 2004), Mentha, Ocimum, Lens (Sabzalian et al., 2014), and others has been studied by several researchers;. In addition, white and green LEDs have shown positive effects on the growth of some species such as Lactuca sativa, and Solanum lycopersicum (Kim et al., 2004; Johkan et al., 2012; Lu et al., 2012). In this sense, white HP-LED lamps can generate a multispectral light unlike that of the narrow light bands produced by single color LEDs.

Although LEDs are used as an artificial flexible lighting source for the growth of seedlings of forest species in the greenhouse (Apostol et al., 2015; Riikonen et al., 2016), their use on the growth of forest trees by plant tissue culture are limited (Astolfi et al., 2012; Gupta and Jatothu, 2013). Studies on the micropropagation 
of woody species, such as $H$. ochraceus, using energy efficient LEDs could lead to reduced costs and more environmentally friendly growing practices. Thus, the aim of this work was to study the effect of HP-LED lighting at different irradiances on growth responses such as shoot and root development and stomatal characteristics of $H$. ochraceus and compare it with the response under fluorescent lighting, usually used in micropropagation.

\section{MATERIALS AND METHODS}

\subsection{Reagents}

IBA, BA, tyamine, glycine, nicotinic acid, pyridoxine, myoinositol, and agar were purchased from Sigma Chemical Co (St. Louis, MO). All other chemicals were obtained from Argentinean commercial sources and were of the highest purity available.

\subsection{Plant material}

H. ochraceus seeds were obtained from populations of adult trees from the northwest of Argentina (Orán, Salta, $\left.23^{\circ} 08^{\prime} 10^{\prime \prime} \mathrm{S} 64^{\circ} 19^{\prime} 20^{\prime \prime} \mathrm{W}\right)$. Seeds were washed and disinfected with sodium hypochlorite solution according to Llorente et al. (2016). Axenic seeds were grown in Woody Plant Medium (Lloyd and McCown 1980) supplemented with $100 \mathrm{mg} \mathrm{L}^{-1}$ myoinositol, $20 \mathrm{~g} \mathrm{~L}^{-1}$ sucrose, and $7 \mathrm{~g} \mathrm{~L}^{-1}$ agar (WPM) and $5 \mathrm{~g} \mathrm{~L}^{-1}$ activated charcoal.

\subsection{Multiplication}

Epicotyls from successful in vitro germinations of halfsiblings was selected for the multiplication stages. Epicotyls were cut (10 to $15 \mathrm{~mm}$ in length) and cultured vertically with the basipetal surface in contact with $65 \mathrm{~mL}$ of WPM supplemented with $20 \mu \mathrm{MBA}$ and $1 \mu \mathrm{M}$ IBA (multiplication medium) in 250-mL glass flasks. Subcultured shoots in the same medium were grown under FL or HP-LED at different irradiances. The multiplication rate (number of shoots per initial explant), node number, shoot length and visual observations through a transparent culture vessel of general aspect (presence/absence of hyperhydricity, necrosis, chlorosis or basal callus) were evaluated after 30,45 and 60 days in all treatments.

\subsection{Rooting}

To reduce variability in the initial physiological status, ramdomly selected shoots from FL and from HP-LED multiplication experiments were respectively used for FL and HP-LED rooting treatments. Shoots of 4-week-old multiplication stage ( $20 \mathrm{~mm}$ in length) were cultured for 3 days in modified WPM [ $1 / 2$ WPM] (mineral salts at half-strength of standard concentration and $6 \mathrm{~g} \mathrm{~L}^{-1}$ agar) and supplemented with $50 \mu \mathrm{M}$ IBA. Then, one shoot per flat bottom glass tube $(100 \times 25$ $\mathrm{mm}$ ) containing $15 \mathrm{~mL}$ auxin-free $1 / 2 \mathrm{WPM}$ was cultured for 42 days under the HP-LED or FL lighting treatments. At the end of the experiments, the following parameters were recorded for each light treatment: percentage of rooted shoots, fresh and dry weights and length of shoots and roots, and numbers of leaves and roots. The presence/absence of basal callus, hyperhydricity, and health of plants were also recorded.

\subsection{Stomata analysis}

After 60 days of culture, the second pair of leaves of three randomly selected shoots from in vitro multiplication assay at $20 \mu \mathrm{mol} \cdot \mathrm{m}^{-2} \cdot \mathrm{s}^{-1}$ were treated with an ascending ethanol gradient, dried using the critical point method, mounted and metalized with goldpalladium. Leaf epidermis were observed and photographed by scanning electron microscopy (SEM) Philips XL-30 TMP(SEM Service, MACN, Buenos Aires, Argentina). Pictures were processed using TSview software (Tucsen Imaging Technology Co., China). The stomatal density (numbers $/ \mathrm{mm}^{2}$ ) and stomata size in abaxial epidermis were measured using at least 50 stomata sampled randomly at $20 \mu \mathrm{mol} \cdot \mathrm{m}^{-2} \cdot \mathrm{s}^{-1}$.

\subsection{Culture conditions}

Shoots were incubated in two sections of a growth chamber with 55-60\% relative humidity, 16-h photoperiod at $25 \pm 2{ }^{\circ} \mathrm{C}$. One section had fluorescent cool daylight tubes (FL), whereas the other one had High Power warm white LED [HP-LED] as light source. The FL source was built on a metal rack $(45 \mathrm{~cm} \times 90 \mathrm{~cm})$ using three Philips T8 tubes $(220 \mathrm{~V})$ and the HP-LED source was built on two aluminum plates $(3 \mathrm{~cm} \times 60 \mathrm{~cm})$ with 12 HP-LEDs $1 \mathrm{~W}$ (12 V) (Demasled-CE Rohs, Argentina). Each HP-LED module was splitted into four equal strips (3 HP-LEDs), each group wired in parallel with the remaining three. Shoots under FL and under HP-LED at different irradiances $\left(15,20,30,40,50\right.$, and $\left.60 \mu \mathrm{mol} \cdot \mathrm{m}^{-2} \cdot \mathrm{s}^{-1}\right)$ were evaluated. The different irradiances were obtained varying the height of the light source from 23 to $30 \mathrm{~cm}$ for HPLED and from 32 to $38 \mathrm{~cm}$ for FL, respect to the base of the culture container. Irradiance was measured weekly over the course of the experiments with a lux-meter 
digital (Schwyz SC105-1, Argentina) and expresed as $\mu \mathrm{mol} \cdot \mathrm{m}^{-2} \cdot \mathrm{s}^{-1} \mathrm{PPF}$. The spectrum distribution and features of the light sources were provided by both manufacturers and showed emission peaks at 400, 440, 490, 550, 615 and 710 for FL and 475 and $550 \mathrm{~nm}$ for HP-LED. The spectral composition of HP-LED showed a lower red (600-700 nm) / blue (400-500 nm) light ratio (0.5) than FL (0.7). Also, HP-LED showed a higher green (500$600 \mathrm{~nm}$ ) / red ratio (3.8) than FL (1.5) and a higher green / blue ratio (1.8) than FL (1.0). The energy consumption for FL and HP-LED source was measured by the multimeter Fluke 434 II (Everett, Washington, USA). Experimental plants were randomly assigned to each light treatment.

\subsection{Experimental design and statistical analysis}

Experiments were performed on the basis of a completely randomized factorial design considering the light source (FL and HP-LED) and irradiance (15, $20,30,40,50$, and $\left.60 \mu \mathrm{mol} \cdot \mathrm{m}^{-2} \cdot \mathrm{s}^{-1}\right)$ as factors. The multiplication experiments consisted of five flask with five shoots for multiplication $(\mathrm{n}=25)$, whereas the rooting experiments consisted of 15 flat bottom glass tube with one shoots for rooting $(n=15)$. All experiments were conducted three times. Analysis of variance with a factorial layout was carried out for all experiments. Means were compared using Tukey's test at 5\% significance level when more than two means were analized. Normality of data was performed by Kolmogorov-Smirnov test and variace homegeinity by Levene test. Regression analysis for rooting parameter were performed. All data were evaluated using SPSS v.21.0 (IBM SPSS, Armonk NY, USA). To analyze global effects for factors and their interactions, a Growth Index (GI) adapted from Larraburu and Llorente (2015) was constructed using all the growth parameters as follows:

EQ-1

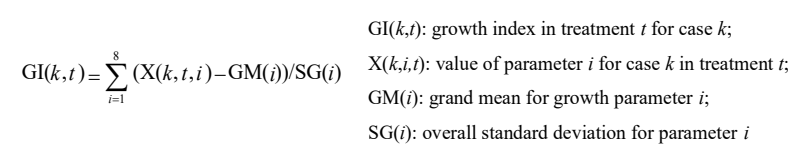

\section{RESULTS}

HP-LED and FL kept the same irradiance throughout the experiment. The energy consumption was $21.0 \mathrm{Wh}$ for HP-LED and 112.2 Wh for FL. Both FL and HP-LED lighting resulted in multiple stem and leafdevelopment of $H$. ochraceus without malformations, hyperhydricity, necrosis, chlorosis or basal callus during in vitro multiplication (Fig. $1 \mathrm{a}-\mathrm{b}$ ).

All data shown normality and variace homogeninity. The factorial analysis showed that the shoot length was affected by light source and irradiance interaction only at 60 days of culture $(f=2.8, p<0.01)$ whereas the node number was affected at three times evaluated $(f=4.1$ to $6.5, p<0.05)$. Light source mean of shoot length obtained under FL was significant higher $(p<0.05)$ than HP-LED at all time evaluated. Also, under FL the shoot length showed a more uniform response than HP-LED at different irradiances. Light intensity mean (LIM) showed a reduction of shoot length and node number by 14 to $44 \%$ under high irradiance (40-60 $\mu \mathrm{mol} \mathrm{m} \mathrm{m}^{-2} \mathrm{~s}^{-1}$ ) in comparison to $15 \mu \mathrm{mol} \mathrm{m} \mathrm{m}^{-2} \mathrm{~s}^{-1}$ at 30,45 and 60 days, although no significant differences $(p \leq 0.05)$ were observed at 45 days of culture (Table 1$)$.

Figure 1 a-d showed that HP-LED induced more proliferation of adventitious shoots than FL with significantly increased of the shoot multiplication rate by $61 \%$ from 20 to $40 \mathrm{mmol} \mathrm{m}^{-2} \mathrm{~s}^{-1}$ after 60 days of culture as compared with FL. The highest multiplication rate occurred at 20 mmol $\mathrm{m}^{-2} \mathrm{~s}^{-1}$, under both light sources. At this irradiance, the multiplication rate values were 3.6, 4.2, and 5.8 under HP-LED, and 2.4, 3.1, and 3.6 under FL, after 30, 45, and 60 days of culture, respectively (Fig. $1 \mathrm{c}-\mathrm{d}$ ).

Leaves of in vitro multiplication shoots of $H$. ochraceus showed anomocytic stomata at both sides of the epidermis under both ligting treatments. The different light source influenced the stomata characteristics. Plants grown under HP-LED increase stomatal density (85\% in abaxial and $152 \%$ in adaxial epidermis) and decrease between 9-23\% stomata size in both epidermis, respect to $\mathrm{FL}$ at $20 \mu \mathrm{mol} \cdot \mathrm{m}^{-2} \cdot \mathrm{s}^{-1}$ (Fig. $1 \mathrm{e}-\mathrm{f}$ ). All the differences were significantly at $\mathrm{p} \leq 0.05$

All rooted shoots showed normal stem, leaf, and root development, without basal callus formation, and no hyperhydricity signs (Fig. 2 a). The ANOVA showed that leaf number, root length, fresh and dry root weights, and rooting percentage were significantly affected by the light source $\times$ irradiance interaction $(\mathrm{f}=2.8$ to $14.1, \mathrm{p}<0.05)$ whereas the other parameters evaluated were not affected (Fig. 2c). Irradiances between 15 and $40 \mu \mathrm{molm}^{-2} \mathrm{~s}^{-1}$ significantly reduced $(76-89 \%)$ the rooting percentages $(p \leq 0.05)$ in shoots grown under HP-LED compared with those grown underFL, which showed no significant differences at different irradiances (Fig. 2 b).

Revista Árvore. 2018;42(5):e420508 

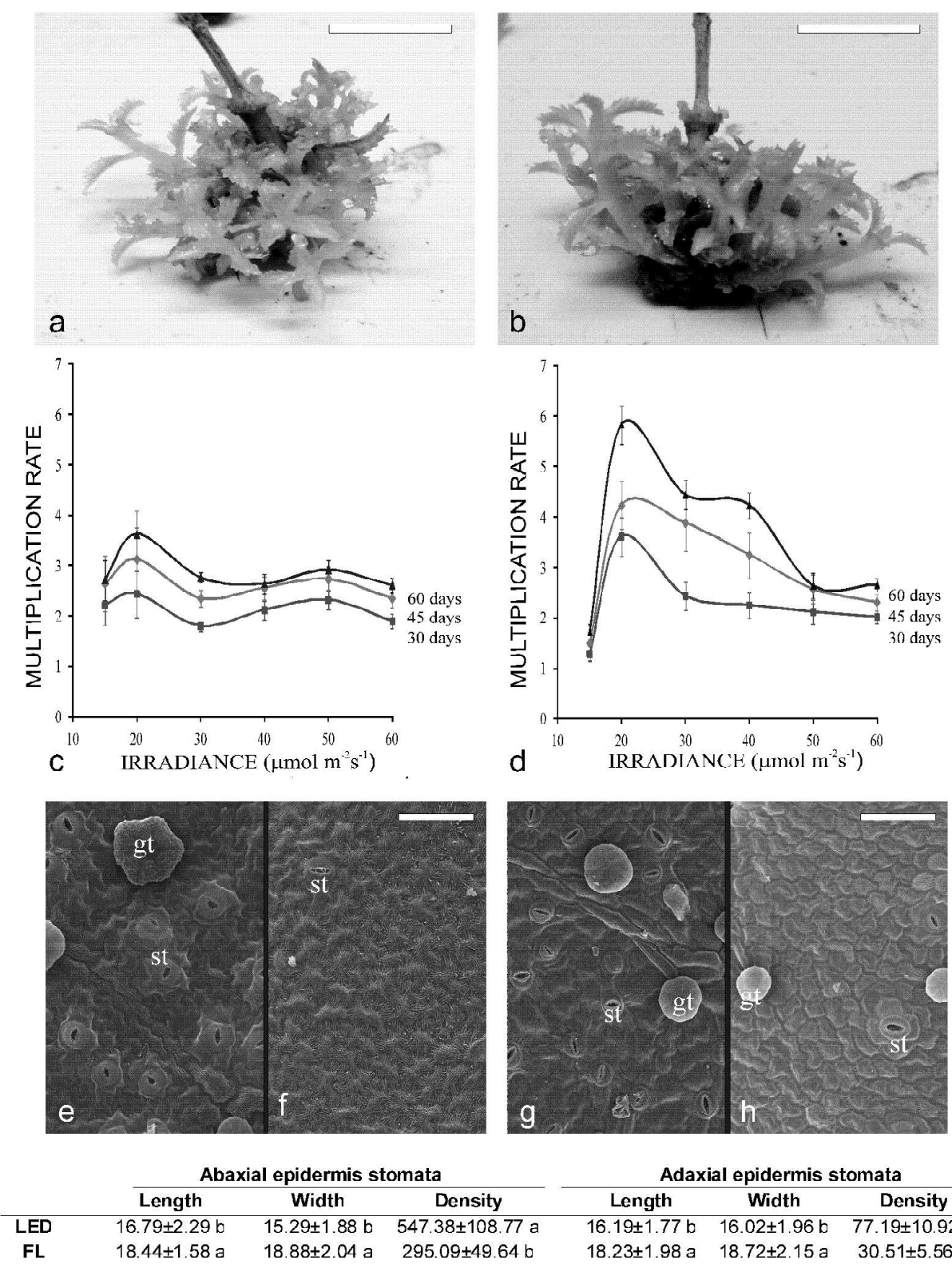

\begin{tabular}{ccc}
\multicolumn{3}{c}{ Adaxial epidermis stomata } \\
\hline Length & Width & Density \\
\hline $16.19 \pm 1.77 \mathrm{~b}$ & $16.02 \pm 1.96 \mathrm{~b}$ & $77.19 \pm 10.92 \mathrm{a}$ \\
$18.23 \pm 1.98$ & $18.72 \pm 2.15 \mathrm{a}$ & $30.51+5.56 \mathrm{~b}$
\end{tabular}

Figure 1 - In vitro multiplication of Handroanthus ochraceus under two types of light source. (a) shoots under fluorescent light (FL); (b) shoots under high power light emitting diodes (HP-LED); bars: $1 \mathrm{~cm}$. Multiplication rate (number of shoots per inicial explant) as a function of irradiance after 30. 45. and 60 days under (c) FL and (d) HP-LED; bars represent standard error. e-i: abaxial (e-h) and adaxial (g,i) epidermis of leaves under $20 \mu \mathrm{mol} \mathrm{m}^{-2} \mathrm{~s}^{-1}$ irradiance FL (e-f) or HP-LED (g-h); gt: glandular trichomes; st: stomata; bars: $50 \mu \mathrm{m}$. Table stomata features: different letters in the same column indicate significant differences between treatments $(\mathrm{p} \leq 0.05)$.

Figura 1 - Multipliçao in vitro de Handroanthus ochraceus sob dois tipos de fontes de luz. (a) brotos sob luz fluorescente (FL); (b) brotos sob diodos emissores de luz de alta potência (HP-LED). Barras: $1 \mathrm{~cm}$. Taxa de multiplicação (número de brotos por broto inicial) em função da irradiância de luz após 30.45 e 60 dias em (c) FL e (d) HP-LED; barras representam um erro padrão. e- $h$ : epiderme abaxial (e-f) e adaxial $(g-h)$ das folhas sob irradiância de $20 \mu \mathrm{mol} \mathrm{m}^{-2} \mathrm{~s}^{-1} \mathrm{FL}$ (e) ou HP-LED(f); gt: tricomas glandulares; st: estômatos. Barras: $50 \mu \mathrm{m}$. Características dos estômatos da tabela: diferentes letras na mesma coluna indicam diferenças significativas entre os tratamentos $(p \leq 0.05)$. 
Table 1 - Mean comparison of growth parameters of Handroanthus ochraceus shoots during in vitro multiplication under different light sources and irradiances after 30, 45, and 60 days of culture.

Tabla 1 - Comparação de meias de parâmetros de crescimento de brotos de Handroanthus ochraceus durante a multiplicação in vitro sob diferentes tipos de luz e irradiações após 30, 45 e 60 dias de cultura.

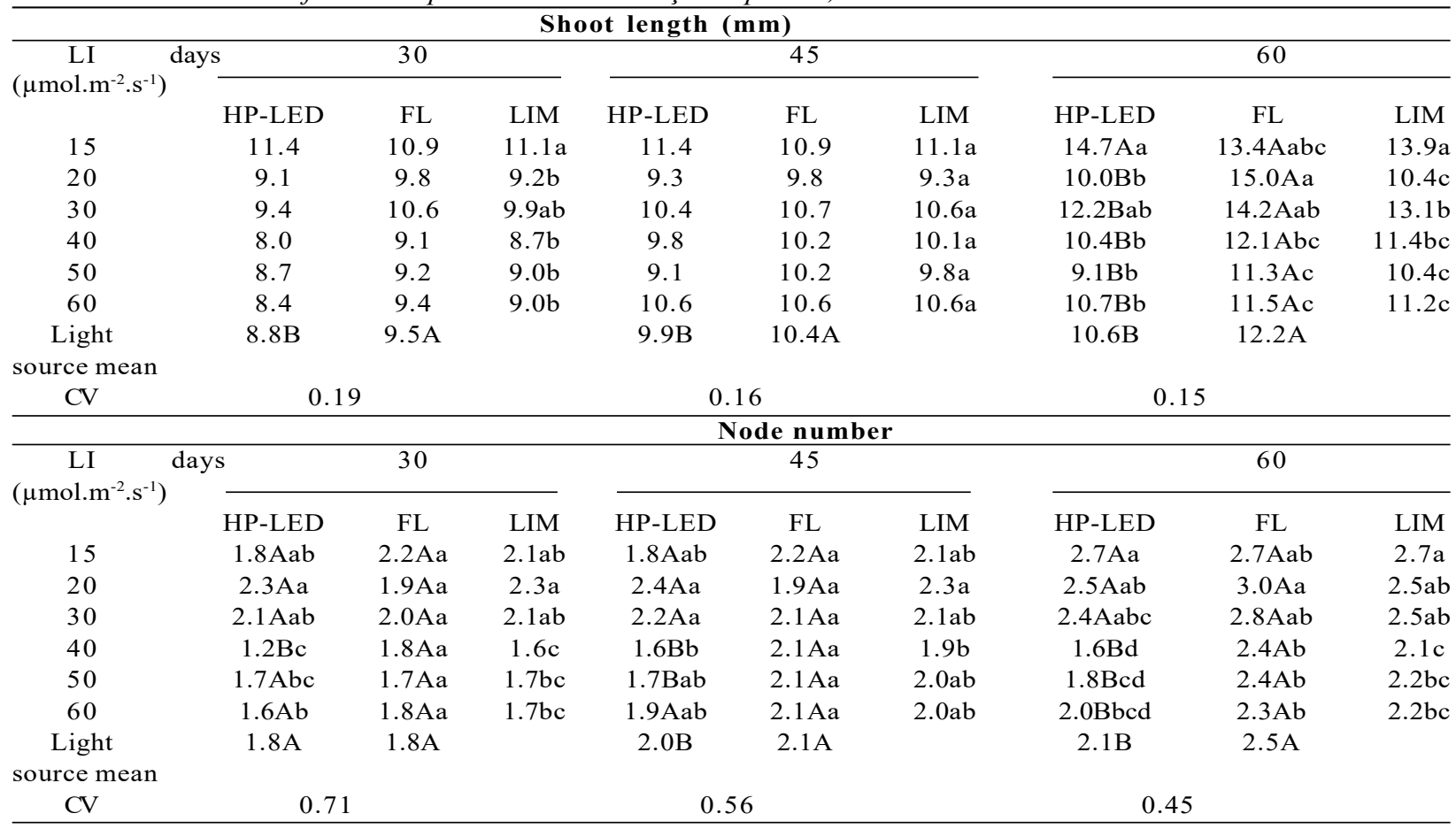

Means followed by different upper case letters in the lines differ from each other for the light source at 5\% of significance level. Different lower case letters in the same column indicate significant differences between light intensity treatments by Tukey's test ( $\mathrm{p} \leq 0.05)$. $\mathrm{n}=$ 75. Means that are not followed by letters show no significant interaction among the treatments. HP-LED: shoots cultured under High Power Light Emitting Diode. FL: shoots cultured under Fluorescent Light. CV: coefficient of variation. LI: light intensity. LIM: light intensity mean.

The means of light source treatments without factors interaction showed that HP-LED irradiances significantly increased shoot length by $20 \%$, shoot fresh weight by $77 \%$ and shoot dry weight by $30 \%$ in comparison to the values under FL (Table 2). In addition, leaf number did not show significant differences among light intensities under HP-LED whereas it showed the highest values in low intensities under FL. Marginal mean of light intensity (LIM) for shoot lengh, fresh and dry weight of shoot and root were higher at upper intensity. Light source means of root parameters showed significant increases $(p \leq 0.05)$ in number and length under FL whereas showed significant decreases in fresh and dry weigth.

The polynomial regression analysis for the light intensity for each light source indicated that the regression had a cubic adjustment in most parameters. The maximum values calculated from the regression curves were around
$50 \mu \mathrm{mol} \mathrm{m} \mathrm{m}^{-2} \mathrm{~s}^{-1}$ for HP-LED for all parameters except root lenght whereas were around $20 \mu \mathrm{mol} \mathrm{m} \mathrm{m}^{-2} \mathrm{~s}^{-1}$ for FL for all parameters except fresh and dry weigth of shoot (Fig. 3).

The results described above were summarized in a growth index (GI) that shows a marked increase at $50 \mathrm{mmol}$ $\mathrm{m}^{-2} \mathrm{~s}^{-1}$ HP-LED respect to those obtained with the other HP-LED intensities and all FL intensities (Fig. 2 b).

\section{DISCUSSION}

HP-LED and FL were evaluated to select the best one for $H$. ochraceus in vitro culture. The multiplication rate obtained under HP-LED $\left(20-40 \mu \mathrm{mol} \mathrm{m}^{-2} \mathrm{~s}^{-1}\right)$ was higher than that obtained under FL and was mainly due to the proliferation of adventitious shoots. Growth stimulation by LED has also been observed in in vitro cultures of other species. For example, beech (Fagus

Revista Árvore. 2018;42(5):e420508 

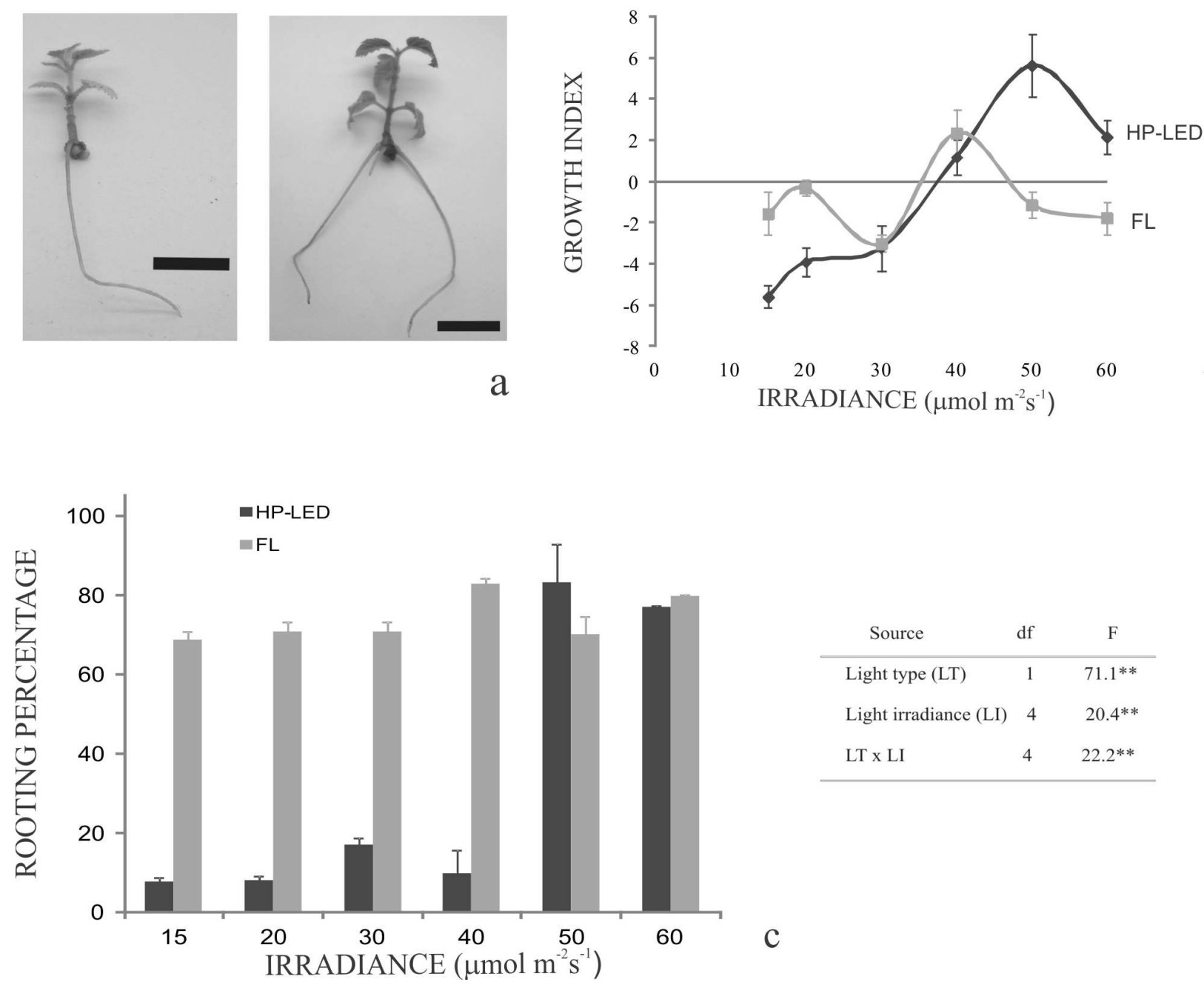

Figure 2 - In vitro rooting of Handroanthus ochraceus after 45 days of culture. (a) left: shoots under fluorescent light (FL); right: shoots under high power light emitting diodes (HP-LED); bar: $1 \mathrm{~cm}$. (b) Growth parameters index (GI) consisting of the sum of the standardized mean of all parameters of $H$. ochraceus plants analyzed as a function of irradiance of FL and HP-LED sources. (c) Rooting percentage as function of irradiance of FL and HP-LED sources and factorial analisis.

Figura 2 - Enraizamento in vitro de Handroanthus ochraceus após 45 dias de cultura. (a) esquerda: brotos sob luz fluorescente (FL); direita: brotos sob diodos emissores de luz de alta potência (HP-LED); barra: $1 \mathrm{~cm}$. (b) Índice de parâmetros de crescimento (GI) consistindo na soma da média padronizada de todos os parâmetros das plantas de H. ochraceus analisadas como função da irradiância de luz das fontes FL e HP-LED (c) Percentagem de enraizamento em função da irradiância de luz de fontes FL e HP-LED e análise fatorial.

sylvatica L.), holm oak (Quercus ilex L.), and wild cherry (Prunus avium) seedlings grown under a wide continuous spectrum LED showed significantly longer shoots than plants grown under FL and also beech had $40 \%$ and $110 \%$ greater shoot fresh and dry matter, respectively (Astolfi et al., 2012). Also, Zantedeschia albomaculata (calla lily) and Vaccinium corymbosum (highbush blueberry) shoot elongation as well as fresh and dry weights were significantly increased when cultures were kept under red LED in comparison to FL (Chang et al., 2003; Hung et al., 2016). Light quality influences plant development and physiology because it affects 
Table 2 - Mean comparisons and factorial analysis of shoot and root growth parameters of Handroanthus ochraceus during in vitro rooting stage on different type and intensity of light after 45 days of culture.

Tabela 2 - Comparações médias e análise fatorial dos parâmetros de crescimento aéreo e raiz de Handroanthus ochraceus durante o estágio de enraizamento in vitro em diferentes tipos e intensidade de luz após 45 dias de cultura.

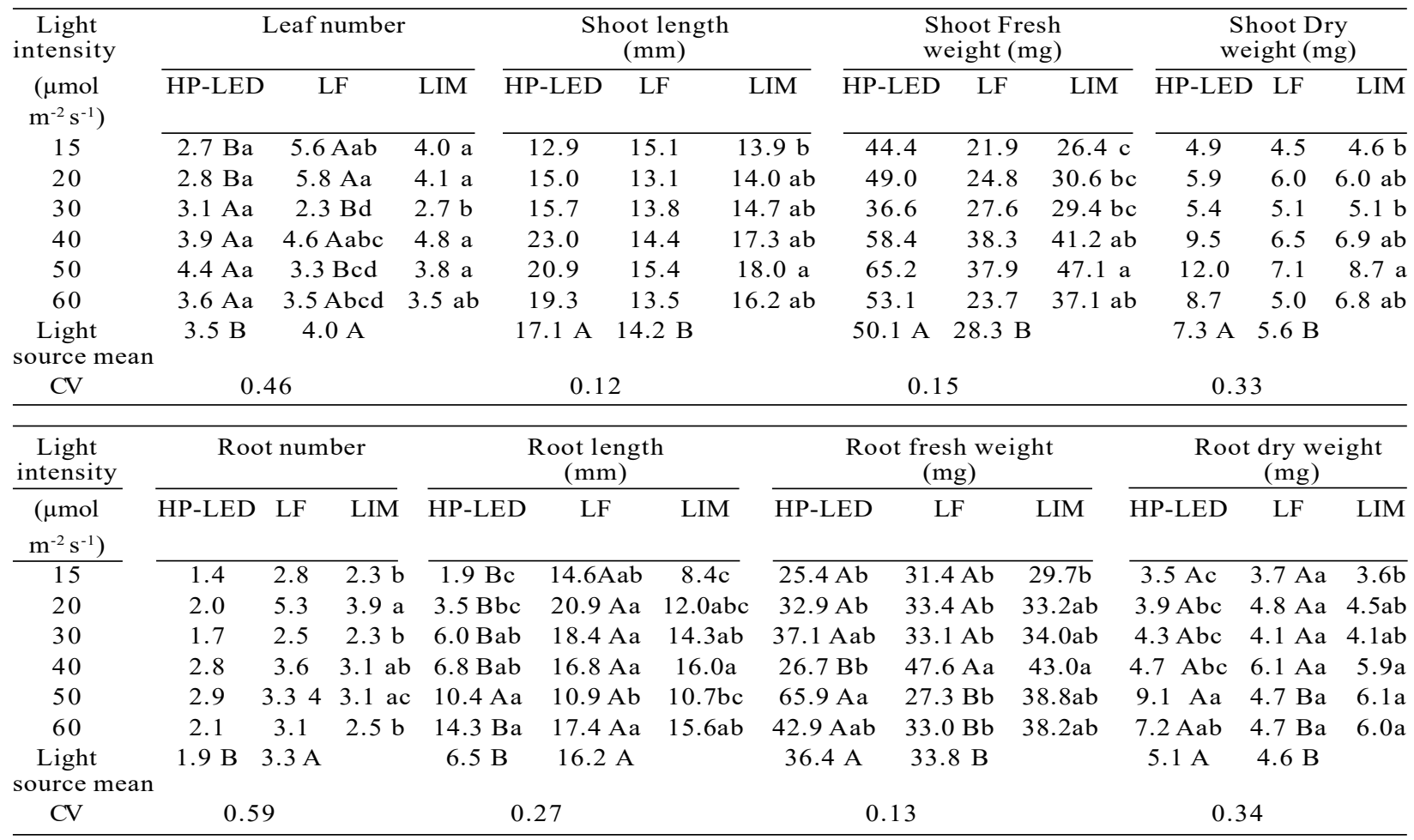

Means followed by different upper case letters in the lines differ from each other for the light source at $5 \%$ of significance level. Different lower case letters in the same column indicate significant differences between light intensity treatments by Tukey's test ( $\mathrm{p} \leq 0.05)$. $n=$ 45. Means that are not followed by letters show no significant interaction among the treatments. HP-LED: shoots cultured under High Power Light Emitting Diode. FL: shoots cultured under Fluorescent Light. CV: coefficient of variation. LI: light intensity. LIM: light intensity mean.

the signaling cascade of specific photoreceptors which change the expression of some genes (Singh et al., 2015). Although the effect of light quality depends on the plant species, in general, blue light suppresses elongation and induces biomass production, green light affects leaf growth and shoot elongation, and red light stimulates photosynthesis, flowering and budding (Johkan et al., 2012; Singh et al., 2015). Previous studies have shown that the combination of red and blue LEDs enhances Mentha and Fragaria growth compared to other monochromatic LEDs (Nhut et al., 2003; Gupta and Jatothu, 2013; Sabzalian et al., 2014). Green light is the least absorbed by plants and is not sufficient to support their growth but, when used in combination with red and blue light, it shows some important physiological effects (Singh et al., 2015). In this sense, supplementation of green light with red and blue LED has been shown to enhance lettuce plant growth (Kim et al., 2004). Since blue light suppresses shoot elongation and red and green lights stimulate growth, the increase in the multiplication rate of $H$. ochraceus in HP-LED in comparison to FL could be related to the wider green light given that red light has less contribution in HP-LED. Moreover, FL induces oxidative processes (Astolfi et al., 2012), which could explain the decrease in the multiplication rate in comparison to that obtained under HP-LED.

The stomata status influence physiological activities such as photosynthesis and transpiration (Xiao-Jing et al., 2011). In general, an increase in stomatal density could allow plants to increase conductance for gas exchange and, thus photosynthetic performance with higher productivity (Schlüter et al., 2003). In this sense,

Revista Árvore. 2018;42(5):e420508 


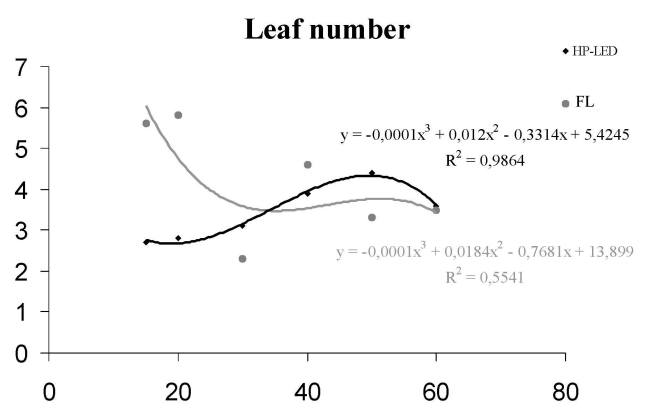

Shoot fresh weight

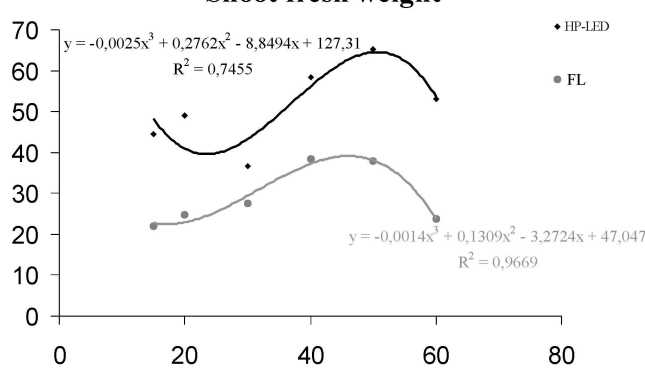

Root number
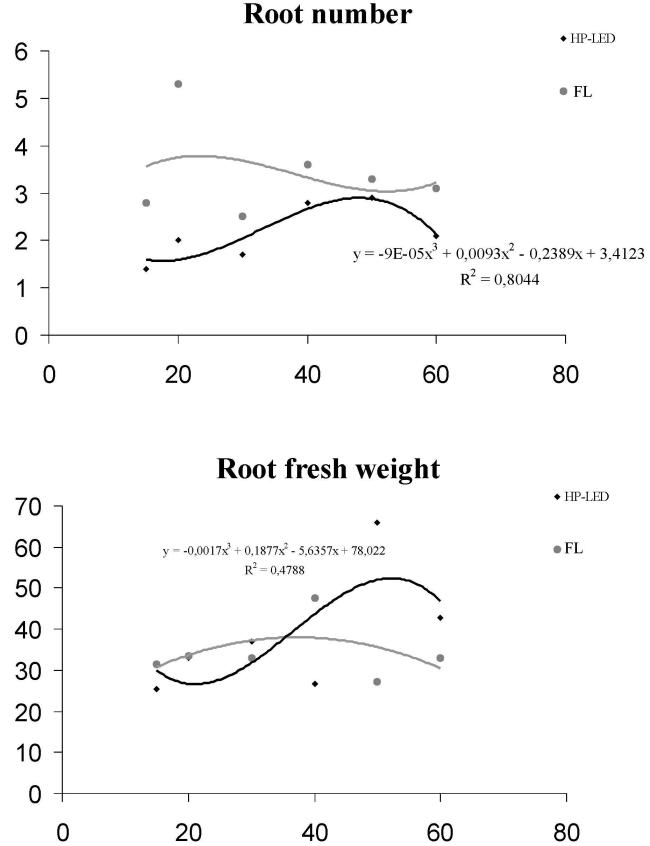

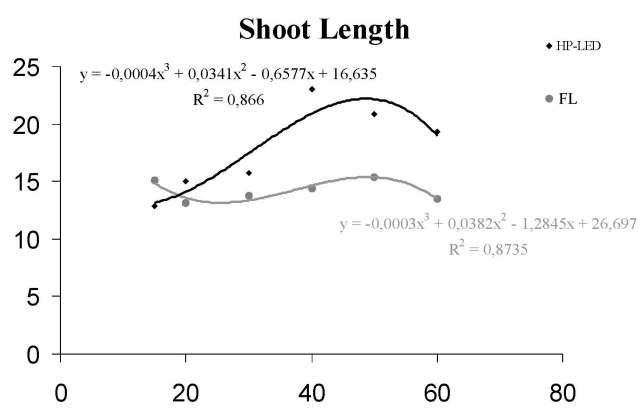

Shoot dry weight
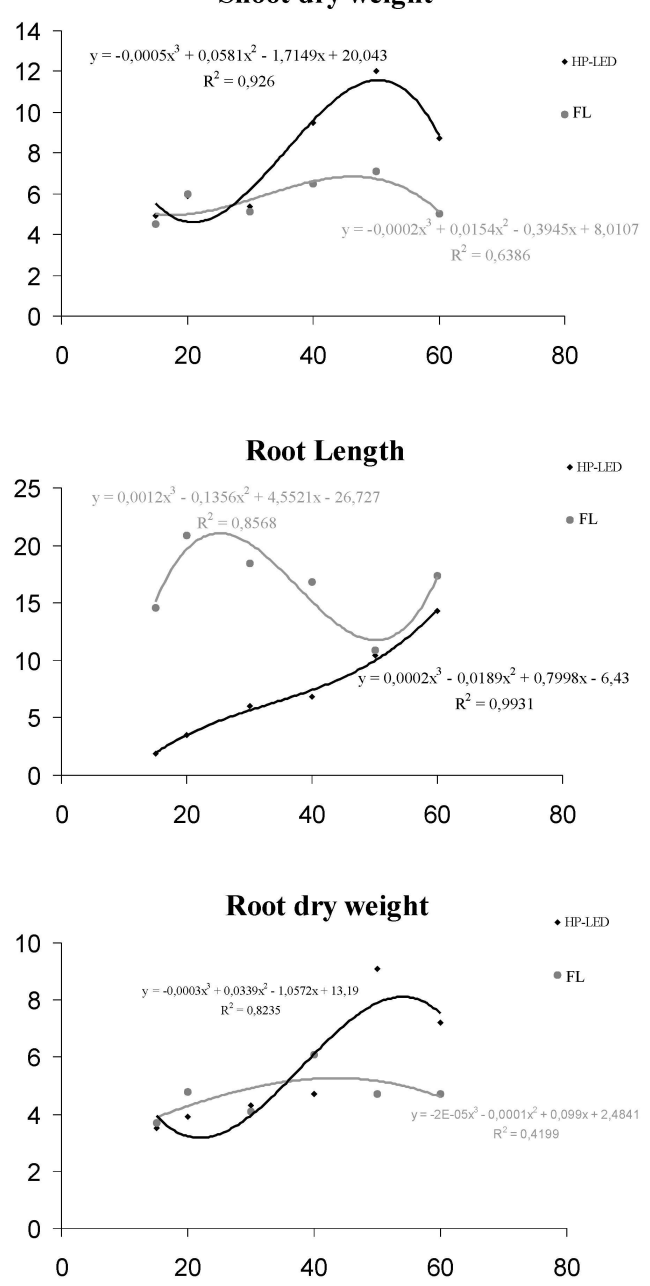

Figure 3 - In vitro rooting of Handroanthus ochraceus under two types of light source. Regression analysis of root parameter respect to irradiance for each light source. Significant regression curves are in the graphic $\left(\mathrm{R}^{2}>0.36\right)$. FL: shoots under fluorescent light HP-LED: shoots under high power light emitting diodes

Figura 3-Enraizamento in vitro de Handroanthus ochraceus sob dois tipos de fonte luminosa. Análise de regressão do parâmetro raiz quanto à irradiância para cada fonte de luz. Curvas de regressão significativas estão no gráfico ( $\left.R^{2}>0,36\right)$. FL: dispara sob luz fluorescente HP-LED: dispara sob diodos emissores de luz de alta potência 
the light source affected stomata density and size in both epidermis of $H$. ochraceus. The increase in stomata density under HP-LED was correlated to a higher multiplication rate, respect FL.

Plant growth and development is affected not only by the light source, but also by the irradiance because both affect photomorphogenesis. For example, Alvarenga et al. (2015) found that the growth of Achillea millefolium differed significantly under different FL irradiances, with high growth parameters at $27 \mu \mathrm{mol} \mathrm{m}^{-2} \mathrm{~s}^{-1}$. Similar results have been observed in Alocasia amazonica, with a better growth response under 15 or $30 \mu \mathrm{mol} \mathrm{m}^{-2} \mathrm{~s}^{-1} \mathrm{FL}$ than under higher irradiance (Jo et al., 2008). This matches that obtained in H. ochraceus grown under FL and HP-LED light sources, which showed a higher multiplication rate under $20 \mu \mathrm{mol}$ $\mathrm{m}^{-2} \mathrm{~s}^{-1}$ and the highest shoot length and node number under 15-30 $\mu \mathrm{mol} \mathrm{m}^{-2} \mathrm{~s}^{-1}$. In contrast, previous studies have shown that the in vitro growth of strawberry (Fragaria $x$ ananassa) under LED light ( $90 \%$ red $+10 \%$ blue) (Nhut et al., 2003) and of two orchids (Phaius spp and Vanda spp) under FL was better under 60-74 $\mu \mathrm{mol} \mathrm{m} \mathrm{m}^{-2} \mathrm{~s}^{-1}$ (Soontornchainaksaeng et al., 2001). Although shoot morphogenesis is stimulated by light, the most favorable irradiance varies with the physiological and hormonal status of each species (George et al., 2008).

Rooting was also affected by light quality. HP-LED induced higher rooting percentage and growth index at $50 \mu \mathrm{mol} \mathrm{m} \mathrm{m}^{-2} \mathrm{~s}^{-1}$ than those obtained with the other HP-LED intensities and all FL intensities. In this sense, HP-LED $50 \mu \mathrm{mol} \mathrm{m}^{-2} \mathrm{~s}^{-1}$ produced the highest root weights, whereas lower irradiances significantly reduced them according to that observed in strawberry (Nhut et al., 2003). Also, Z. albomaculata root fresh and dry weigth increased, whereas its root number and root length decreased under blue LED $50 \mu \mathrm{mol} \mathrm{m}^{-2} \mathrm{~s}^{-1}$ in comparison to FL at the same intensity (Chang et al., 2003). On the other hand, the highest values of root number and root length of $H$. ochraceus were obtained under low FL irradiances $\left(20 \mu \mathrm{mol} \mathrm{m}^{-2} \mathrm{~s}^{-1}\right)$ according to that observed in Achilea millefolium under $27 \mu \mathrm{mol} \mathrm{m}^{-2} \mathrm{~s}^{-1} \mathrm{FL}$ (Alvarenga et al., 2015) and Alocasia amazonica under $30 \mu \mathrm{mol}$ $\mathrm{m}^{-2} \mathrm{~s}^{-1} \mathrm{FL}$ (Jo et al., 2008). High FL irradiance has been considered detrimental for rooting of some woody species because it may increase leaf temperature, transpiration, phenolic compound biosynthesis, peroxidase activity, and photo-oxidation (Fogaça and Fett-Neto, 2005; Tombesi et al., 2015), which would reduce the number and length of roots.

Revista Árvore. 2018;42(5):e420508
In addition, light intensity and quality determine asymmetric distribution of auxin which produces differential growth of plant organs (Kurepin and Pharis, 2014). Therefore, the positive effect of HP-LED on rooting percentage and root weight in $H$. ochraceus under high irradiances could be linked to increases of endogenous auxin levels, as it has been suggested for Eucalyptus saligna and E. globulus cuttings (Fogaça and FettNeto, 2005).

The differences between FL and HP-LED observed in $H$. ochraceus rooting may be related to the light spectral composition in according to the changes induced by the different blue/red ratios of LED and FL in strawberry (Nhut et al., 2003). These authors observe higher root development by decreasing LED red/blue ratio. In coincidence, HP-LED used in $H$. ochraceus rooting provided lower red/blue ratio than FL ( 0.5 and 0.7 , respectively).

The low energy consumed by HP-LEDs results in savings of $81 \%$ compared with lighting costs of FL. Also, LEDs generate very little heat, thereby minimizing the need for an extensive cooling system in the plant growth chamber, and saving additional energy (Nhut et al., 2003). In this way, the use of HP-LED may allow achieving an ecological growth chamber with the same performance as a conventional chamber, without the environmentally hazardous components currently used in lighting with FL (Bourget, 2008).

\section{CONCLUSIONS}

The HP-LED irradiation system used in the present study showed several advantages over FL in the micropropagation of yellow lapacho (H. ochraceus), such as a significant increase in the shoot multiplication rate from 20 to $40 \mu \mathrm{mol} \mathrm{m} \mathrm{m}^{-2} \mathrm{~s}^{-1}$, and of growth parameters and growth index from 50 to $60 \mu \mathrm{mol} \mathrm{m}^{-2} \mathrm{~s}^{-1}$ at the rooting stage. Then, HP-LED can be used as FL substitute on in vitro culture of $H$. ochraceus.

\section{ACKNOWLEDGEMENTS}

This research was supported by a grant from the Department of Basic Sciences, National University of Luján, Argentina.

\section{REFERENCES}

Alvarenga IC, Pacheco FV, Silva ST, Bertolucci SK, Pinto JE. In vitro culture of Achillea 
millefolium L. quality and intensity of light on growth and production of volatiles. Plant Cell, Tissue and Organ Culture. 2015;122(2):299-308.

Apostol KG, Dumroese RK, Pinto JR, Davis AS. Response of conifer species from three latitudinal populations to light spectra generated by lightemitting diodes and high-pressure sodium lamps. Canadian Journal of Forest Research. 2015;45(12):1711-9.

Apóstolo NM, Larraburu EE, Gil MN, Zapater MA, Llorente BE. In vitro and ex vitro germination of three Handroanthus species (Bignoniaceae). Bonplandia. 2016;25:5-15.

Astolfi S, Marianello C, Grego S, Bellarosa R. Preliminary investigation of LED lighting as growth light for seedlings from different tree species in growth chambers. Notulae Botanicae Horti Agrobotanici Cluj-Napoca. 2012;40:31-8.

Bourget CM. An introduction to light-emitting diodes. HortScience. 2008;43:1944-6.

Chang HS, Charkabarty D, Hahn EJ, Paek KY. Micropropagation of calla lily (Zantedeschia albomaculata) via in vitro shoot tip proliferation. In Vitro Cellular \& Developmental Biology - Plant. 2003;39(2):129-34.

Fogaça CM, Fett-Neto AG. Role of auxin and its modulators in the adventitious rooting of Eucalyptus species differing in recalcitrance. Plant Growth Regulation. 2005;45:1-10.

George EF, Hall MA, De Klerk GJ. Plant propagation by tissue culture. $3^{\text {rd }}$. ed. Springer: The Background; 2008.

Gupta S, Jatothu B. Fundamentals and applications of light-emitting diodes (LEDs) in in vitro plant growth and morphogenesis. Plant Biotechnology Reports. 2013;7:211-20.

Huante P, Ceccon E, Orozco-Segovia A, SánchezCoronado ME, Acosta I, Rincón E. The role of arbuscular mycorrhizal fungi on the early-stage restoration of seasonally dry tropical forest in Chamela, Mexico. Revista Árvore. 2012;36(2):279-89.

Hung CD, Hong CH, Kim SK, Lee KH, Park JY, Nam MW, Choi DH, Lee HI. LED light for in vitro and ex vitro efficient growth of economically important highbush blueberry (Vaccinium corymbosum L.). Acta Physiologiae Plantarum. 2016;38:1-9.

Jao RC, Fang W. An adjustable light source for photo-phyto related research and young plant production. Applied Engineering in Agriculture. 2003;16:601-8.

Jo EA, Tewari RK, Hahn EJ, Paek KY. Effect of photoperiod and light intensity on in vitro propagation of Alocasia amazonica. Plant Biotechnology Reports. 2008, 2:(3)207-12.

Johkan M, Shoji K, Goto F, Hahida S, Yoshihara T. Effect of green light wavelength and intensity on photomorphogenesis and photosynthesis in Lactuca sativa. Environmental and Experimental Botany. 2012;75:128-33.

Justiniano MJ, Nash D, Fredericksen TS. Ecología y silvicultura de especies menos conocidas.

Tajibos o Lapachos Tabebuia spp. Gomes ex AP de Candolle Bignoniaceae. Santa Cruz: El Pais; 2000.

Kim HH, Goins GD, Wheeler RM, Sager JC. Greenlight supplementation for enhanced lettuce growth under red-and blue-light-emitting diodes.

HortScience. 2004;39:1617-22

Kurepin LV, Pharis RP. Light signaling and the phytohormonal regulation of shoot growth. Plant Science. 2014;229:280-9.

Larraburu EE, Llorente BE. Azospirillum brasilense enhances in vitro rhizogenesis of Handroanthus impetiginosus (pink lapacho) in different culture media. Annals of Forest Science. 2015;72(2):219-29.

Llorente BE, Alasia MA, Larraburu EE.

Biofertilization with Azospirillum brasilense improves in vitro culture of Handroanthus ochraceus, a forestry, ornamental and medicinal plant. New Biotechnology. 2016;33:32-40.

Lloyd GB, McCown BH. Commercially-feasible micropropagation of Mountain laurel, Kalmia latifolia, by use of shoot tip culture. Proceedings of International Plant Propagation Society. 1980;30:421-6

Lu N, Maruo T, Johkan M, Hohjo M, Tsukagoshi 
S, Ito Y, et al. Effects of supplemental lighting with light-emitting diodes (LEDs) on tomato yield and quality of single-truss tomato plants grown at high planting density. Environmental Control Biology. 2012;50:63-74.

Nhut DT, Takamura T, Watanabe H, Okamoto K, Tanaka M. Responses of strawberry plantlets cultured in vitro under superbright red and blue light-emitting diodes (LEDs). Plant Cell, Tissue and Organ Culture. 2003;73:43-52.

Riikonen J, Kettunen N, Gritsevich M, Hakala T, Särkkä L, Tahvonen R. Growth and development of Norway spruce and Scots pine seedlings under different light spectra. Environmental and Experimental Botany. 2016; 121:112-120.

Sabzalian MR, Heydarizadeh P, Zahedi M, Boroomand A, Agharokh M, Sahba MR, et al. High performance of vegetables, flowers, and medicinal plants in a red-blue LED incubator for indoor plant production. ý Agronomy for Sustainable Development . 2014;34(4):879-86.

Schlüter U, Muschak M, Berger D, Altmann T. Photosynthetic performance of an Arabidopsis mutant with elevated stomatal density (sdd1 1) under different light regimes. Journal Experimental of Botany. 2003;54(383):867-74.
Singh D, Basu C, Meinhardt-Wollweber M, Roth B. LEDs for energy efficient greenhouse lighting. Renewable and Sustainable Energy Reviews. 2015;49:139-47.

Silva AEA, Davide A, Faria J, Melo D, Abreu G. Germination studies on Tabebuia impetiginosa Mart. seeds. Cerne. 2004;10:1-9.

Soontornchainaksaeng P, Chaicharoen S, Sirijuntarut $M$, Kruatrachue M. In vitro studies on the effect of light intensity on plant growth of Phaius tankervilliae (Banks ex L'Herit) B1. and Vanda coerulea Giff. Science Asia. 2001;27:233-237.

Tombesi S, Palliotti A, Poni S, Farinelli D. Influence of light and shoot development stage on leaf photosynthesis and carbohydrate status during the adventitious root formation in cuttings of Corylus avellana L. Frontiers in Plant Science. 2015;6:973.

Xiao-Ying L, ShiRong G, ZhiGang X, XueLei J, Tezuka T. Regulation of chloroplast ultrastructure, cross-section anatomy of leaves, and morphology of stomata of cherry tomato by different light irradiations of light-emitting diodes. HortScience. 2011;46(2):217-21 